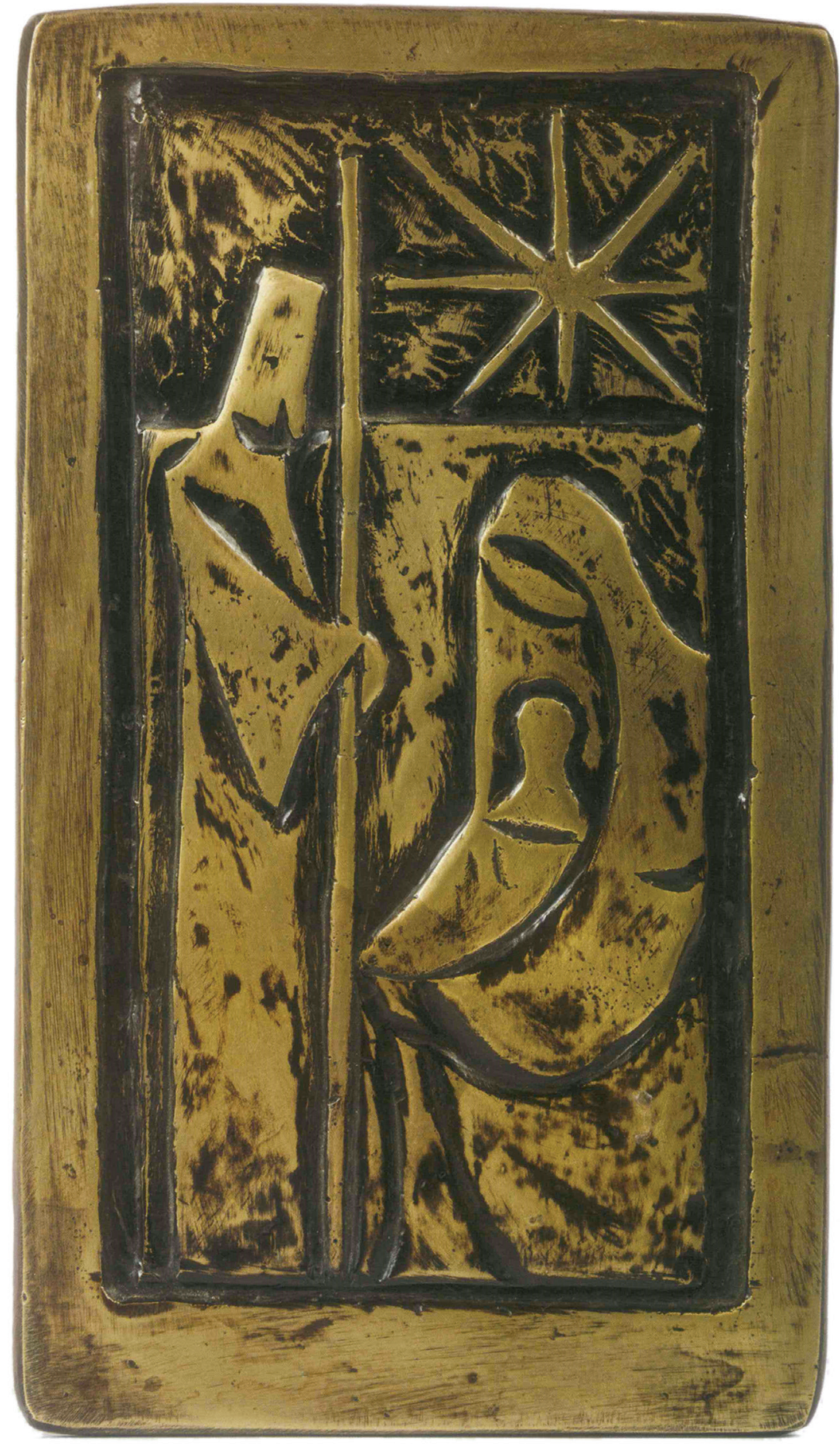





\section{LA RELIGIOSIDAD DURANTE EL PERIODO HISPÁNICO COMO CONTEXTO PARA EL SURGIMIENTO DE LA NOVENA}

Si bien la Navidad y su celebración estuvieron presentes en el periodo hispánico mediante la adaptación de las prácticas propias de la tradición europea, para el caso concreto del Nuevo Reino de Granada es preciso entender el funcionamiento y la dinámica del fenómeno religioso en el periodo en mención para dilucidar cómo surgió la Novena para el Aguinaldo (1784), puesto que la religiosidad católica barroca redefinió no solamente las creencias, sino también los valores, prácticas y comportamientos de la sociedad neogranadina durante la administración hispánica. Es así como este primer capítulo mostrará cómo la religiosidad cristiana católica sirvió de fundamento moral para la sociedad del Nuevo Reino de Granada a través de la implementación de algunas prácticas religiosas que pueden considerarse de larga duración ${ }^{1}$ y las cuales lograron establecerse como habitus ${ }^{2}$ entre la población.

Dado que en la época hispánica la Iglesia incidía en los principales momentos de la vida de los individuos: el nacimiento, el matrimonio y la muerte, estos aspectos, junto con los procesos de evangelización y educación, sirvieron en términos ideológicos al funcionamiento del orden hispánico. La evangelización tuvo un papel fundamental puesto que permitió en buena medida organizar y darle coherencia al proyecto de la Corona española en América,

1 F. Braudel (1988) plantea que la larga duración puede entenderse como el proceso por el cual las estructuras o prácticas culturales logran una estabilidad notable y evidente en el tiempo sin limitarse por marcos geográficos, ideológicos o temporales, de manera que se torna resistente a influencias exteriores, por lo que son difícilmente modificables o susceptibles de ser eliminadas en un corto tiempo.

2 P. Bourdieu entiende el habitus como el conjunto de prácticas generadas por las condiciones de vida de los grupos sociales, así como la forma en la que estas prácticas vislumbran una relación concreta con la estructura social, esto es, el "espacio de los estilos de vida" (2007, p. 477). 
el cual pretendió la unificación del pensamiento y las creencias religiosas mediante un plan estatal —en la diferencia cultural — que transfería los ideales de "humanización" a través de la fe cristiana y su doctrina. Desde esta perspectiva, ideales como la salvación, la caridad y la humildad estuvieron presentes en la sociedad y se materializaron en obras pías y apoyo a la evangelización y a la labor eclesiástica por parte del grupo de los "notables" o privilegiados. Sin embargo los agentes llamados a inculcar y fortalecer la moral religiosa y los deberes sociales fueron las ordenes religiosas clericales y regulares; estas contribuyeron a institucionalizar una ética cristina soportada en ciertos valores y virtudes como la caridad, la compasión y la humildad, que influyeron en las celebraciones religiosas y en la educación.

Aquellas virtudes fueron el resultado de la inserción social y cultural de la noción cristiana de Retribución, un fenómeno que desarrolló un sistema de gratificación moral y seguridad existencial en tanto se concretase una posición de entrega espiritual que había de ser cumplida en aras de la obtención de la gracia divina ${ }^{3}$. De acuerdo con las concepciones expuestas por Léon-Dufour (1965), este pensamiento ha llevado a algunos teólogos a desarrollar un ideal mediado por la reciprocidad en la intención de los actos del hombre, es decir, un principio en el que se argumenta que todas las acciones contienen dentro de sí una consecuencia determinada por la voluntad ("buena o mala") envuelta dentro de ellas, y que básicamente son el resultado natural del obrar humano con repercusiones tanto individuales como colectivas.

Este tema de la retribución se ha convertido en una explicación teológica sencilla de la esencia promotora del actuar humano de acuerdo con la voluntad de Dios, ya que manifiesta el espíritu misional que los hombres deben estar dispuestos a recrear en la tierra y a materializar en el orden social y cultural si desean salir victoriosos en su deseo de triunfar sobre la muerte. Todo ello sin duda fue parte de la esencia que dinamizó la conformación del mencionado estilo de vida predominante en la sociedad de este periodo; allí, la fuerte idealización del castigo eterno como resultado de la desviación de los mandatos divinos se

3 De acuerdo con lo dilucidado por Léon-Dufour (1965), Dios crea y se entrega sin medida al hombre y a la naturaleza que ha creado para él, por ello afirma: "El hombre delante de Dios es el pobre, el mendigo, el servidor, ya que no el esclavo, que no tiene nada sino lo que el amo le otorga día tras día. La retribución aparece, pues, no como el objetivo de la vida religiosa, sino como un fruto normal del servicio de Dios" (p. 691). Es precisamente esta concepción del "deber responder" ante las gracias ya adquiridas, lo que de alguna manera fundamenta esos pasos reglamentarios que contribuirán notoriamente al ideal salvífico propuesto por el discurso cristiano. 
tradujo en la exaltación del valor condensado en el principio de la solidaridad, principio a su vez cristalizado en los actos benefactores dirigidos a aquellos que personificaban la pobreza espiritual o evidenciaban carencias materiales.

Desde esta perspectiva, la caridad se torna entonces una práctica religiosa y social de gran relevancia entre la población americana, en función de aquello que Lavrín (1998) entiende como "la economía de la salvación eterna", es decir, la promoción del aparato eclesiástico de diversas actividades a modo de "inversión espiritual", mediante ejercicios o prácticas religiosas como dar limosnas, rezar novenas y hacer donaciones, entre otras, con el fin de disminuir los sufrimientos en el purgatorio y alcanzar la vida eterna. Así pues, las "buenas conductas" de una u otra forma se reflejaron en actos devocionales propios del cristianismo católico en la medida en que aseguraban la salvación de las almas dispuestas a cumplir con dichos comportamientos acordes con la moral pública y religiosa.

\section{Las fiestas religiosas y el tiempo litúrgico: la continua búsqueda de la salvación}

La mentalidad religiosa hispánica en el Nuevo Mundo, producto del mestizaje, de la asimilación y de la hibridación cultural, permitió a la población neogranadina desenvolverse en un marco espiritual, pero también festivo dado que la mayoría de las celebraciones religiosas eran de carácter público, lo cual promovía la interacción social. Algunas fiestas paganas propias de la cosmogonía indígena fueron revestidas con la sacralidad propia del cristianismo, haciendo que las prácticas devocionales se constituyeran en una forma de encuentro social que tenía lugar en los templos, plazas mayores y calles. Para ello se emitían decretos que permitían la organización de fiestas conmemorativas relacionadas con la vida de Jesucristo, al tiempo que las diferentes ordenes religiosas presentes en el territorio neogranadino celebraban también los días de los santos o advocaciones a las cuales ofrecían un culto particular. La fiesta religiosa, como vivencia grupal y ritual con fines espirituales y trascendentales, combinaba el trasfondo religioso con el lúdico permeándolo de cierta sacralidad, de modo que la evocación del patrono local, un santo en particular o las advocaciones propias consolidaron las festividades sagradas como espacios de salvación individual y colectiva.

Entre las órdenes religiosas que hicieron presencia en el Nuevo Reino de Granada estaban los dominicos, los franciscanos, los agustinos y los jesuitas. Los dominicos llegaron hacia 1552 a Popayán, cuando fray Francisco Carvajal fundó el primer convento, se dedicaron a la evangelización y enfrentaron pro- 
blemas tales como la muerte de varios de sus miembros en cumplimiento de la misión evangelizadora en territorios indígenas. Los franciscanos se guiaban por las virtudes y propuestas espirituales predicadas por san Francisco de Asís, que descansaban en la pobreza ${ }^{4}$, la oración, el ayuno y la penitencia. Al parecer, "su primitivo convento debió ser fundado entre 1568 y 1570 por fray Jodoco Riquer, flamenco, de quien se decía era hijo natural de Carlos V. Este mismo religioso fundó el convento de franciscanos en Quito" (Aragón, 1930, p. 195), y posteriormente la orden contaría con colegios de misiones en Quito y en Cali.

Por su parte, los agustinos hicieron presencia desde 1578 en Popayán y se caracterizaron por la gran misión evangelizadora de sus integrantes y su elocuencia y oratoria. Los jesuitas estaban regidos por los preceptos de san Ignacio de Loyola y daban relevancia a la Santísima Trinidad y a la búsqueda del magis y el minus — del más y del menos_ para mayor gloria de Dios, del mejor servicio a los hombres, la mayor abnegación, el esfuerzo constante y el conocimiento continuo, siguiendo fielmente a Jesús pobre y humilde. En 1633 esta orden adquirió por cuenta de una cédula real la facultad de fundar casas en América y de este modo contaron con presencia en Popayán, Santafé, Neiva y Putumayo.

Las advocaciones y devociones particulares de cada orden ampliaron entonces la gama de festividades y forjaron el predominio de las celebraciones religiosas a modo de ejercicios espirituales en el marco de la "economía de la salvación”. Entre las fiestas religiosas más relevantes para el periodo hispánico se encontraban la conmemoración de Nuestra Señora del Topo, la Virgen del Rosario, san Joseph — san José-, Semana Santa, Corpus Christi, la Inmaculada Concepción, el Nacimiento de Jesús y la Epifanía. Estas celebraciones eran organizadas por las diferentes ordenes religiosas que cumplían la misión evangelizadora y a ellas debían asistir las principales autoridades civiles por orden expresa del virrey, como lo muestra un documento del siglo XVIII para Maracaibo (hoy Venezuela).

4 Dada la importancia que representa este principio, es preciso aclarar que de acuerdo con las reflexiones hechas por Gratien de París (1932) sobre san Francisco de Asís, se puede afirmar que el Santo "ama la pobreza solamente porque la pobreza había sido amada por Jesús, 'porque Jesús se hizo pobre por nosotros en este mundo’ [...] la contemplación asidua del misterio de la Cruz; luego, el ideal nacido de este amor, ideal en el que la pobreza más extrema ocupa el primer lugar y conduce el alma a la imitación de Cristo por una semejanza íntima y perfecta con Él en su vida activa y contemplativa, humilde, pobre y paciente; después, la manera personal de realizar este ideal, manera simple, objetiva, leal, activa y alegre, o en otros términos, optimista y llena de animación y entusiasmo; y finalmente, los frutos de alegría, de serenidad, de libertad, de paz y universal amor que abundan en su alma” (párr. 34). 


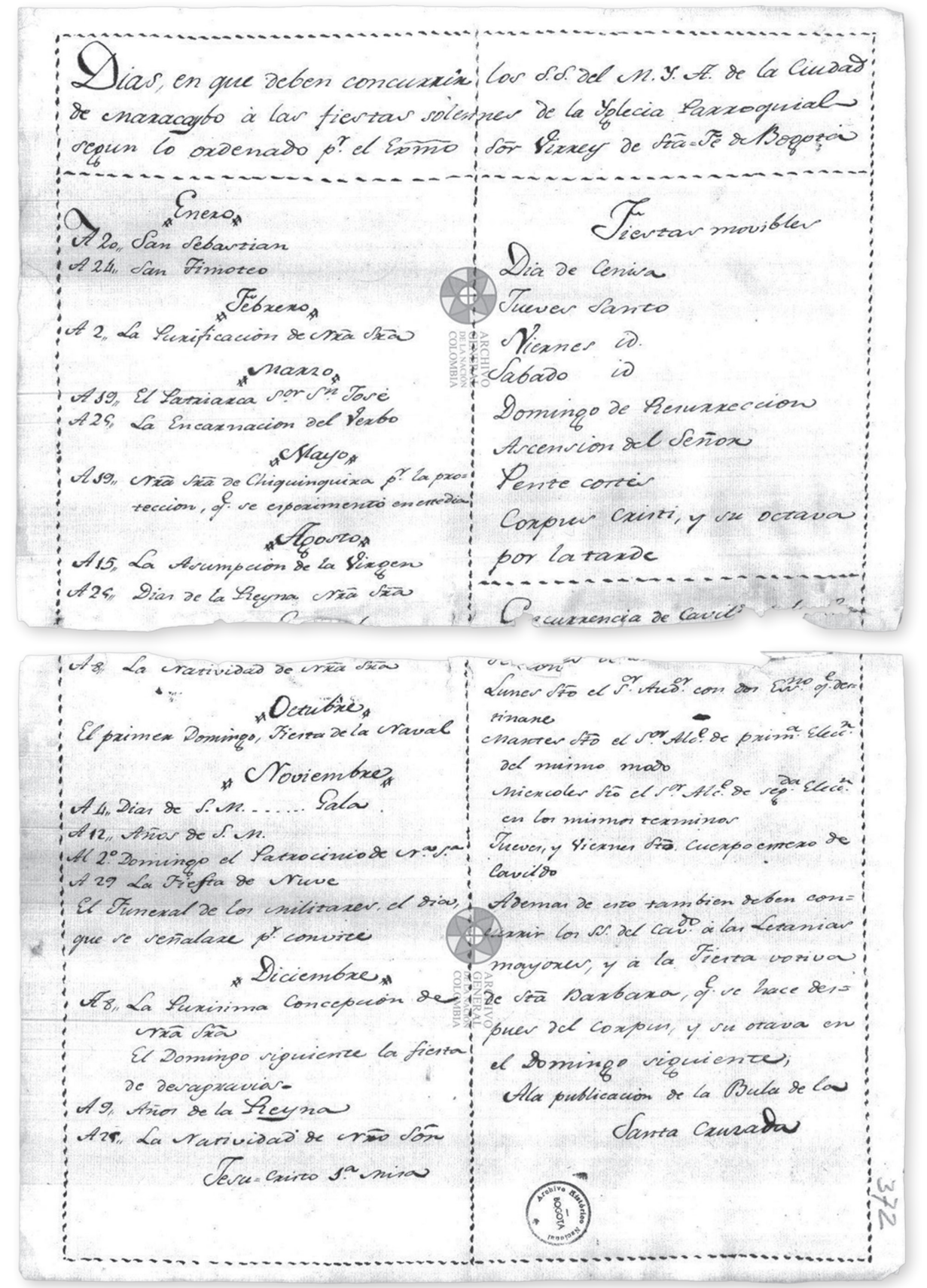

Figura 1. Fiestas religiosas a las que debía asistir el cabildo de Maracaibo según lo ordenado por el virrey de Santafé (s. f.)

Fuente: AGN, Colonia, Cabildos: SC, 7, 11, D. 27, ff. 371-372. 
Para 1778, las autoridades civiles de Popayán se reunieron y establecieron las celebraciones religiosas a las que debían asistir y el atuendo que correspondía usar en los eventos de carácter público:

En la ciudad de Popayán a cinco de Octubre de mil setecientos setenta y ocho ańos los señores del muy ilustre Cabildo justicia y regimiento de ésta ciudad se congregaron en su sala capitular [...] se trataron los asuntos siguientes: Tratose sobre los días en que el Cabildo debe concurrir a las funciones de la iglesia y resolvieron los señores precisamente en los siguientes

\author{
Santa Bárbara \\ San Francisco de Borja \\ Los Santos Auxiliadores \\ La octava de San Juan \\ Nuestra Señora de la Concepción \\ La Asunción = La Naval \\ La Purificación \\ San Pedro \\ Los días de los patriarcas por convite \\ Los de Pascuas \\ Corpus y la Octava \\ Ramos \\ Jueves y Viernes Santo \\ Ceniza $=$ Rogativa \\ Procesión del Viernes Santo \\ Y los días del Rey y Príncipe y las Honras \\ [...] qué a las funciones públicas debe concurrir el Cabildo \\ con el uniforme de casaca y con calzones de terciopelo negro liso \\ y chupa de tisú todo de oro y para Cabildo de Sala, vestido Negro \\ y media blanca [...] (Archivo Central del Cauca, 1778, f. 187v).
}

Estas prácticas religiosas de carácter público incluían una ritualidad que exigía cierta solemnidad, aunque la Inmaculada Concepción, el Corpus Christi o la Navidad eran desde luego las más importantes. En la organización y celebración de procesiones, misas y novenas asociadas a estas, "el Cabildo, además de participar activamente en estos tramos de la ciudad y tener amplias facultades y privilegios, también debía encargarse de financiar las festividades 
religiosas y civiles" (Aristizábal, 2011, p. 62). Esto corrobora la adopción de las fiestas religiosas como escenarios de socialización y punto de referencia para ordenar el tiempo en el periodo hispánico. Es así como los días festivos en el Nuevo Reino de Granada a partir del calendario de 1689, guardan estrecha relación con la tradición española de vincular el uso del tiempo al año litúrgico cristiano:

A estos días festivos se debían agregar las llamadas "Fiestas móviles" que eran el miércoles de Ceniza, el Domingo de Ramos, el jueves y el viernes Santo, los segundos días de las pasquas de Resurrección y Navidad... En conclusión, los cristianos guardaban 84 días festivos, es decir, la cuarta parte de un ańo, si sumamos a ellos 19 días de vacaciones formalizados por la iglesia... Si agregamos los 52 Domingos, las 52 tardes de los Sábados y los 10 días de vacaciones en navidad, se tiene otro cuarto de año libre. Es decir, durante 172 días no se laboraba. Durante los siglos XVI y XVII solo un $53 \%$ del tiempo anual era dedicado a las labores productivas, $y$ el $47 \%$ al servicio de Dios y su gloria... Es este equilibrio entre lo divino y lo mundano lo que hace tan importante a la Iglesia y su práctica en la historia del ludismo en el Nuevo Reino de Granada (Lara, 2012, pp. 364-365).

En la sociedad del periodo hispánico los ciclos temporales y santorales ordenaban el tiempo del individuo, pero también el del grupo social. Las fiestas de santos marcaron la temporalidad colectiva evidenciando que en el periodo de dominación española todos los momentos de la vida estaban permeados por una actividad religiosa, es decir, que el orden temporal se sustentaba en lo sagrado incluso en la vida común y ordinaria.

Había una concepción cíclica del tiempo en estas sociedades tradicionales que se expresaba en la abundante celebración de fiestas y que marcaba los tiempos de la siembra, cosecha, matrimonios, bautizos, negocios, etc. La unidad básica de todo el tiempo es el año marcado por las fiestas y celebraciones que, en un momento fueron tanto religiosas como civiles. Las fiestas, de alguna manera, eran prácticas simbólicas que organizaban la vida pero que también ayudaban a conjurar las incertidumbres de la naturaleza [...] Aunque en Colombia no hay estaciones, sin embargo, se tienen 
fiestas de invierno (diciembre y enero), las de primavera (cuaresma y Pascua), las de verano (San Juan y Corpus Christi) y de otońo (fiestas patronales). El calendario festivo europeo fue adaptado a estos países por la dialéctica cristianismo - religiones indígenas (Arboleda, 2011, p. 109).

Las expresiones religiosas como cultos, devociones, sacramentos y liturgias son de alguna forma prácticas simbólicas en la medida en que vinculan al ser humano con lo sagrado y por tanto alteran su cotidianidad. El elemento fundamental que permite la permanecía y solidez de estas prácticas simbólicas es la autoimplicación, que genera el involucramiento del individuo con el grupo mediante un compromiso tanto individual como colectivo. Por esta razón, las expresiones religiosas permiten a los diferentes actores sociales redefinirse y además reafirmarse como comunidad teniendo siempre un proyecto común que para el periodo hispánico bien pudo ser la salvación de las almas, la salvación de un alma en particular, o el beneficio de una comunidad entera. Para este fin se recurría a la repetición de diversos actos simbólicos — procesiones, misas, novenas, rogativas, etc. - que dan continuidad al sistema de creencias y valores instituidos por la Iglesia y consolidan los distintos símbolos religiosos al hacer referencia a lo sobrenatural o a lo sagrado.

Sin embargo el ideal de la salvación abarca entonces no solo el plano espiritual sino también el terrenal, dado que con el ejercicio de algunas prácticas religiosas se buscaba el bien común para que de una u otra forma se garantizara el bien individual de los miembros de la sociedad. En Popayán, hacia 1714, por ejemplo, se acordó hacer un novenario a la Virgen del Rosario para que cesara el invierno:

En la muy noble y leal ciudad de Popayán a diez y ocho de diciembre de mil setecientos y catorce años los señores del cabildo justicia y regimiento della se juntaron en su ayuntamiento como lo han de uso y costumbre a tratar y conferir las cosas tocantes al servicio de su majestad bien y utilidad de la república y en este estado dijeron que se halla esta ciudad atribulada con la continuación de las aguas de que resulta total perdida de las sementeras y granos y se acordó que este dicho cabildo vaya al convento del Seńor Santo Domingo y pida al reverendo padre prior de él se saque la imagen de Nuestra Señora del Rosario y se ponga en novena y rogativa para que se apiade su divina majestad y conceda alguna serenidad 
y para ello cada uno de los señores del dicho cabildo según sus antigüedades alumbrará un día a la misa y rosario a que asistirá todo este dicho cabildo y lo mismo harán todos los vecinos desta dicha ciudad a quienes se les dará noticia y al fin de dicho novenario se sacará dicha imagen de Nuestra Señora en procesión por la plaza mayor y calles acostumbradas y para dicho día se convidarán las religiones y clerecía que lo hará los señores regidores Don Juan Alvarez de Uría alcalde provisional y Don Antonio de Caicedo, con lo cual y por no haber otra cosa que tratar se cerró este cabildo y lo firmaron sus mercedes sin el escribano por estar enfermo (Archivo Central del Cauca, 1714, f. 30).

Cinco ańos más tarde, en febrero de 1719, debido al fuerte verano y las consecuencias que esto acarrearía para cosechas y pastos para el ganado, se acordó hacer un novenario a la misma Virgen del Rosario:

[...] Pueden resultar gravísimos inconbenientes, asi de enfermedades, como se perdiese las sementeras de __ y trigos y demás frutos con que mantiene esta ciudad y los besinos y los pastos para los ganados por la mucha seca que se experimenta de que en otras ocasiones por lo mismo sean experimentado pestes y porque en semejante necesidad y por no haver remedio umano es preciso recurrir al piadoso __ de la divina __ y al de su Santísima Madre Nuestra Señora del Rosario, haciéndole un novenario de rogativa acordaron se haga dicho novenario empezándose desde el viernes beynte y quatro de este mes en cuyo día para principio de el se sacara la santísima imagen en procesión dando buelta por la plaza mayor con las luces que sacara cada persona para lo qual se dará noticia al Reverendo pdre prior del convento [...] (Archivo Central del Cauca, 1714, f. 32).

Las manifestaciones religiosas pasaron entonces a formar parte de la vida cotidiana a través de la celebración de misas, procesiones y demás como maneras de elevar peticiones y reclamar la intervención divina en toda ocasión, principalmente cuando la población se veía amenazada por terremotos, pestes y guerras, situaciones que consideraban perjudiciales para la existencia y motivaban la reunión del pueblo en torno de la fe, como ocurrió en el caso de la rogativa a la Virgen del Rosario para modificar las condiciones de invierno 
y sequía, respectivamente. De hecho, la organización del tiempo litúrgico muestra una fuerte relación entre las fiestas religiosas y el inicio y fin de ciclos ambientales y temporalidades anuales:

[...] se organizó el calendario eclesiástico dividido en tres grandes ciclos o tiempos, a saber: La Navidad, la Pascua y Pentecostés, aunque algunos juntan los dos últimos en un ciclo llamado Pascua, el primero comienza con el adviento como preparación a la Navidad; luego de ella se encuentra la Epifanía, que anuncia al mundo el advenimiento de Cristo y coincide con el solsticio de invierno y el principio del año solar (Hartmann y Velásquez, 2004, p. 28).

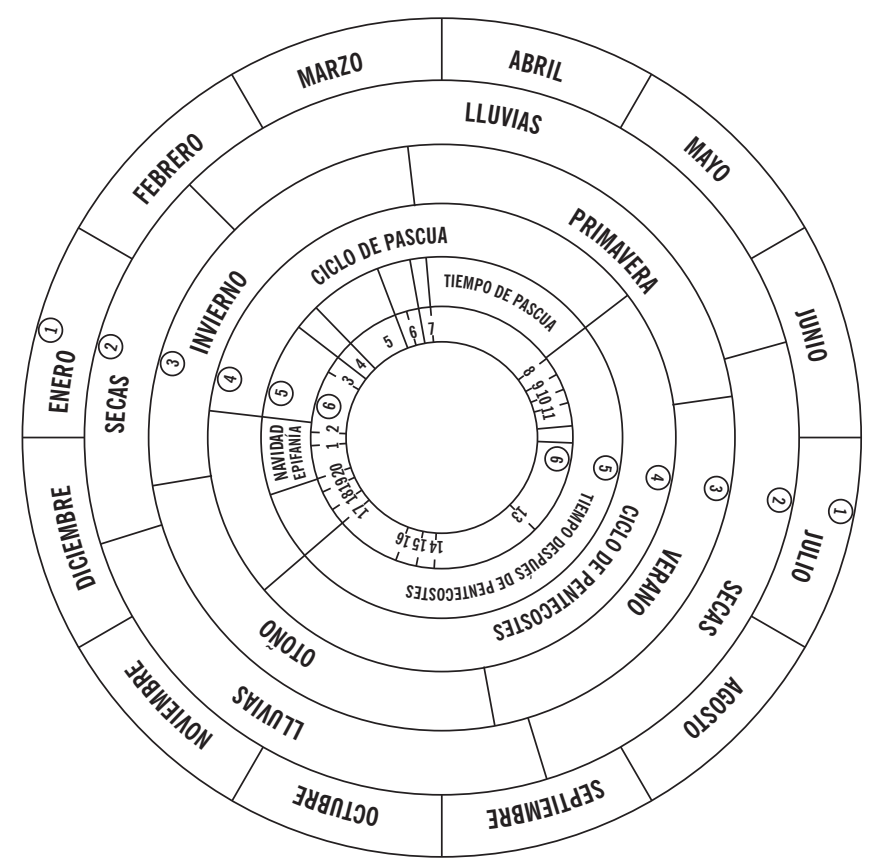

FIESTAS

1. Circuncisión (enero)

2. Epifanía (enero)

3. Purificación (febrero)

4. Carnaval y Miércoles de ceniza (movibles)

5. San José (18 de marzo)

6. Jueves y Viernes Santo (movibles)

7. Pascua de Resurrección (movible)

8. Pentecostés (movible)

9. Santísima Trinidad (movible)

10. Corpus Christi (movible)

11. Santos auxiliadores (4 de junio)

12. San Juan y su octava (junio)

13. Asunción (junio)

14. Virgen del Rosario (7 de octubre)

15. San Francisco de Borja (octubre)

16. San Pedro de Algantana (19 de octubre)

17. Santa Catalina (noviembre)

18. Santa Bárbara (diciembre)

19. Concepción (8 de diciembre)

20. Navidad (24 de diciembre)

(1) MESES DIVIDIDOS

(2) MESES DIVIDIDOS

(3) ESTACIONES PARA

(4) CICLOS DEL AÑO

(5) AÑO LITÚRGICO

(6) FIESTAS PARA

Figura 2. Calendario de fiestas religiosas con ciclos litúrgicos y épocas secas y de lluvia.

Fuente: Hartmann y Velásquez, 2004, p. 30.

De este modo, las muchas celebraciones religiosas que tenían lugar en el periodo hispánico buscaban contribuir a la "economía de la salvación" mediante la recordación constante del deber de enaltecer lo sagrado y de paso organizar 
la vida de la población con el sonido mismo de las campanas, que indicaba el tiempo de realización tanto de las actividades cotidianas en relación con las horas de estudio y trabajo, el llamado a misa o a cualquier evento público, como de las fiestas, que incluían misas solemnes con la asistencia de tribunales y personas distinguidas, las representaciones de comedias, corridas de toros, danzas de indios, luminarias, fuegos artificiales y hasta el temido fandango - tachado de inmoral por los bailes y la cantidad de aguardiente involucrado-.

Los calendarios servían entonces para marcar el paso del tiempo y recordar las fechas importantes en la vida eclesiástica y religiosa de la sociedad neogranadina:

En 1788 se imprimió el primer calendario neogranadino en la imprenta traída en tiempo del virrey Manuel Antonio Flórez (1776-1782). En comunicación al Consejo de Indias, el virrey Caballero y Góngora describe las finalidades de esta publicación, para que "no sólo en esta capital, sino en la mayor Parte de los lugares de este Reino, puedan saber los días que son de Gesta con obligación sólo de Misa o de no poder trabajar, las vigilias y abstinencias, los días en que viven las demás noticias que son consiguientes y de que antes carecían con falta de habilidad y aún de y cumplimiento de muchas obligaciones que exige la religión cristiana y la disciplina”. No debe olvidarse que este tipo de calendarios eran comunes en los países católicos.

Un ejemplo neto de la naturaleza esencialmente religiosa del año civil, se puede ver también en el "Almanaque de las Provincias Unidas del nuevo Reyno de Granada para el año bisiesto de 1812, Tercero de nuestra Libertad, calculado por Don Francisco Josef de Caldas". Precede al calendario una referencia histórica que nadie discutía: "Epocas de la Historia Santa y Eclesiástica [...]: De la Creación según el texto hebreo, 5812. De la muerte de Abel, 5682 [...]; del nacimiento de NUESTRO SEÑOR JESUCRISTO LA EPOCA MAS CELEBRE DEL UNIVERSO Y EL CENTRO DE TODOS LOS DESIGNIOS DEL SEÑOR SOBRE LA SALUd DEL GENERO HUMANO, 1812 (Cárdenas, 2004, p. 404).

La población hispánica funcionaba en torno a un calendario construido con base en la mentalidad religiosa de la época, que centrada en la salvación de las almas permeaba todos los estamentos sociales a través de la institución 
de lo sagrado, aquello que permite llenar de significado la experiencia humana y consolidar el vínculo de creencia y fe en algo para dar consistencia a los comportamientos consigo mismo y con los demás miembros de la sociedad. Es así como la devoción religiosa y "las buenas obras" lograban abrir las puertas del cielo, es decir, cumplir con el ideal de la salvación como proyecto común mediante la caridad y la humildad que soportaron el modelo benefactor sustentado en la ayuda al "otro". En consecuencia, las prácticas caritativas estaban asociadas a las celebraciones religiosas de los santos, a las novenas y a las rogativas y fiestas patronales, aunque desde el periodo hispánico ha sido la temporada decembrina aquella que se caracteriza no solo por ser festiva sino plena en generosidad.

\section{Educar con arte, catecismos y novenas: la enseńanza de los valores cristianos}

$\mathrm{Al}$ igual que las celebraciones y fiestas religiosas permearon la vida de la sociedad neogranadina en el periodo hispánico, el ámbito de la evangelización más importante y efectivo fue la educación, puesto que a través de ella la Iglesia difundió los ideales espirituales, modelos de vida y formas de comportamiento. Para tal fin, las comunidades religiosas presentes, a la cabeza de los procesos tanto de evangelización de la población indígena y esclava, como de la enseńanza para los demás miembros de la sociedad del Nuevo Mundo, establecieron desde mediados del siglo XVI las primeras escuelas, las cuales mantuvieron una relación directa con las órdenes religiosas durante todo el periodo hispánico. De este modo, la enseñanza de la religión católica y su sistema de valores, centrado en la moral cristiana, estuvo vigente en los diferentes planes de estudio, incluso en los implementados por las escuelas públicas creadas a partir de la segunda mitad del siglo XVIII.

Las clases se dividían en primeras letras, estudios menores y estudios mayores, sin que existiera una relación directa entre la edad del estudiante y su nivel de aprendizaje. Las primeras letras se enfocaban en la enseñanza de la lengua castellana y las operaciones aritméticas básicas, pudiendo encargarse de esta labor un tutor particular o alguna escuela conventual. Al concluir esta etapa, se podían iniciar los estudios menores, que se centraban en el aprendizaje del latín, y posteriormente se comenzaban los estudios mayores en colegios mayores o universidades. Así, se formaban individuos con ciertos fundamentos académicos, pero profundamente conocedores y respetuosos de 
los misterios sagrados de la religión católica y sus valores como sustento para "actuar en sociedad".

En la medida en que el propósito de la educación para la época no era otro que reproducir un conjunto de verdades preestablecidas por la doctrina, la fe y la moral católicas para moldear las creencias y estructuras mentales de los sujetos, unificando de cierta manera sus formas de actuar y pensar, es posible entender la educación como una práctica religiosa en sí misma al promulgar el ideal de la salvación y reproducir las lógicas existentes en cuanto al orden del mundo y de la sociedad. Esto se hacía mediante el control de todo lo que se decía, leía y veía, aprovechando diversas herramientas pedagógicas que recurrían a la repetición y la observación de imágenes acordes con las enseñanzas y preceptos de la Iglesia.

En torno a los fines sociales asignados a la enseñanza, y en general a toda práctica educativa, fines esencialmente religiosos, se delineó el tipo de sujeto que se buscaba formar [...] y se delimitó también el tipo de discurso y de saber en el cuál habría que formar, tal como correspondía, al mismo tiempo, al carácter de la institución formadora, es decir, a la iglesia, como monopolizadora total de los procesos educativos en la sociedad colonial. Eran fines y saberes de actuación y consistencia muy práctica, pero que se estructuraban en torno a un eje de apariencia inmaterial: la salvación del alma. Por eso el sujeto de la institución fue durante ese periodo concebido, principalmente, como sujeto religioso, encontrándose de esta manera una gran complementariedad entre el saber dominante, el tipo de sujeto a formar y la institución que controlaba los procesos de formación (Silva, 1984, p. 60).

La formación del sujeto hispánico en América en cuanto a adquisición de conocimientos iba entonces de la mano con la enseñanza de preceptos eclesiásticos como la humildad y la caridad, para lo cual se usaron como instrumentos pedagógicos fundamentales los catecismos, las novenas, algunas obras de arte y, desde luego, las oraciones aprendidas de viva voz. Estos no solo se utilizaban con fines religiosos, sino que fueron implementados en el aprendizaje de una lengua o en la historia del mundo, dado que se podían desplegar en público o en privado, en grupo o individualmente. La importancia de los discursos, la palabra de Dios y el conjunto de verdades académicas y 
religiosas se divulgó y transmitió principalmente a través de una herramienta fundamental: el catecismo5.

El método catequístico de preguntas y respuestas fue utilizado como una técnica de instrucción popular, sencilla y práctica, para transmitir enseñanza a los alumnos. Consiste en la organización de temas, capítulos y partes en forma de preguntas, con sus respectivas respuestas. La palabra catecismo viene de la voz griega kathejismós, que significa "repetición de viva voz" (Ocampo, 1997, párr. 2).

Los catecismos desempeñaron entonces un papel fundamental en la difusión de los preceptos cristianos y sirvieron para enseñar la doctrina católica a la población neogranadina, especialmente la indígena, que poco conocimiento tenía sobre teología, pero que gracias al ejercicio de pregunta-respuesta estaba en capacidad de expresar su fe.

En el siglo XVI aparecieron dos catecismos cristianos que tuvieron gran influencia en España e Hispanoamérica: La Cartilla de la doctrina cristiana, del padre Jerónimo Martínez de Ripalda, impresa en 1591, y la Doctrina cristiana del padre jesuita Gaspar Astete, publicada en el año 1599, la obra que más se ha editado en el mundo, llegando a más de seiscientas ediciones. El Catecismo Astete - muy conocido por los colombianos hasta mediados del siglo XX, como la Urbanidad de Carreño y la Historia de Henao y Arrubla—, se caracterizó por la síntesis de preguntas y respuestas,

5 Para la madre Marta Inés Restrepo, oDN, los catecismos son métodos sencillos de transmisión de valores y virtudes religiosas a modo resúmenes de la enseñanza de los maestros. Según ella, la Didaché, que data del siglo I, puede considerarse el primer catecismo cristiano al servicio de la transmisión de las costumbres judeocristianas primitivas orientadas sobre todo a la no violencia en su vida de perseguidos a causa de su fe (comunicación personal, 9 de diciembre de 2015). En la historiografía, los catecismos religiosos aparecen en el siglo VIII en forma de "compendio histórico". Inicialmente trataban sobre la creación del mundo y explicaban algunas oraciones fundamentales de la religión cristiana. No obstante, el modelo catequístico relacionado exclusivamente con la religión católica se consolidó con el Concilio de Trento en 1546, cuando se propuso como modelo el catecismo romano en lengua latina y vulgar. Pero los catecismos no solamente hacían referencia a asuntos de la religión católica, sino que también eran usados en las escuelas para enseñar las cuestiones políticas e ideas emergentes, así como las directrices para ser un "buen ciudadano" a partir de la historia universal y la historia patria. 
siguiendo un plan: el saber (Fe), el hacer (Mandamiento), el orar (Oración) y el recibir (Sacramento) (Ocampo, 1997, párr. 4).

De esta forma, circularon diversos catecismos siendo el más reconocido el escrito por el padre Astete, y existieron algunos dedicados exclusivamente a la evangelización de la población indígena. Un ejemplo de estos se encuentra en el capítulo 30 de las Constituciones Sinodales de 1606 sobre "la doctrina christiana que se a de enseñar, conforme al concilio de Lima" (transcrito en Pacheco, 1955), el cual resultaba de gran utilidad para los curas de "yndios" en su ejercicio evangelizador.

\author{
Cathecismo breve. \\ ay. \\ Pregunta. —Dezidme ay Dios? - Resp. — Sí Padre, Dios \\ P. Quántos dioses ay? - R. Uno solo no más. \\ P. Dónde está ese Dios? - R. En el cielo y en la tierra y \\ en todo lugar. \\ P. Quién es Dios? - R. Es el Padre, y el Hijo, y el Spíri- \\ tu Sancto que son tres personas y un solo Dios. \\ P. Cómo son tres personas y un solo Dios? - R. Porque de \\ estas tres personas el Padre no es el Hijo, ni el Spíritu \\ Sancto, y el Hijo no es el Padre ni el Spíritu Sancto, - \\ y el Spíritu Sancto no es el Padre ni el Hijo, pero todas \\ tres personas tienen un mismo ser y assí son no más de \\ un solo Dios.
}

Figura 3. Cathecismo breve (parte inicial).

Fuente: Constituciones Sinodales de 1606, f. 30r, transcrito en Pacheco, 1955, p. 196.

Otro ejemplo que resulta interesante es el Catecismo en el lenguaje de los indios cunacunas escrito en 1722, una traducción que pone sobre la mesa el afán de catequizar y evangelizar a este grupo indígena, habitante de las tierras bajas del Pacífico - junto a los chocoes- a través de sus propios elementos culturales, con el objetivo de que interiorizara la fe cristiana en su propia lengua, en una oración y en un ritual ajeno a sus costumbres como lo era el Padre Nuestro. 
Conpefirmo en lenguale de los mos Gonacunas

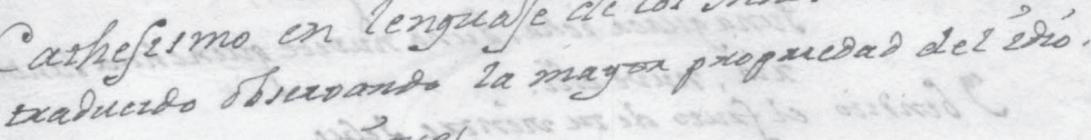

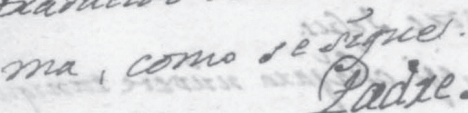

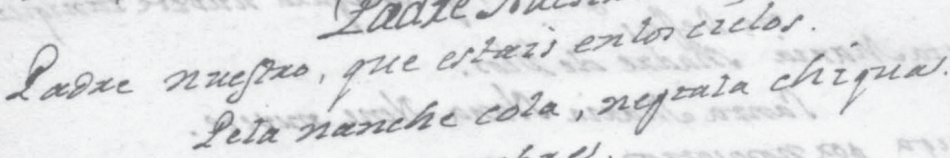

Sannfrado sea me nombxe.

Nere riveretrin.

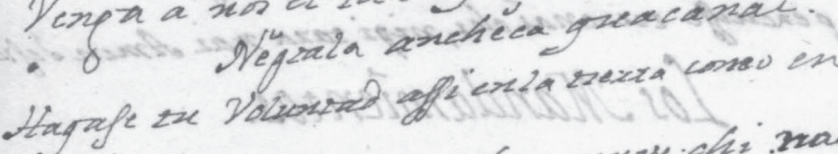
elcieto.

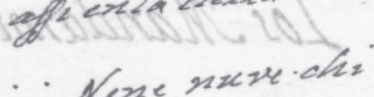

mak a tañzquí?

Cuefra ipi Nene num numerel

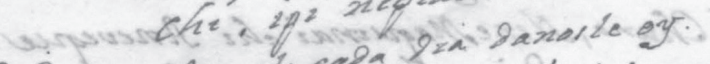

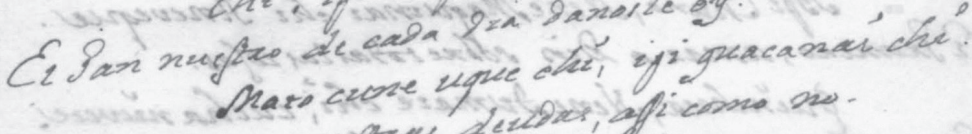

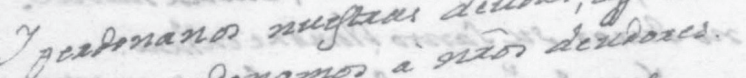

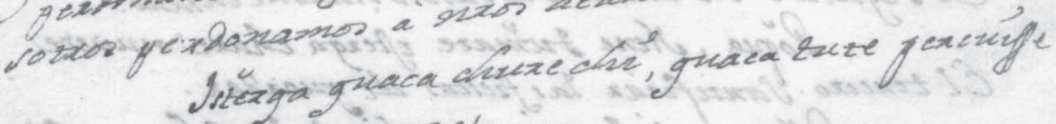
clive, pivered. atong

Ino nos desoes caer en tentacion, mes laba.

In nos desoes caex en tentacion, mes laked

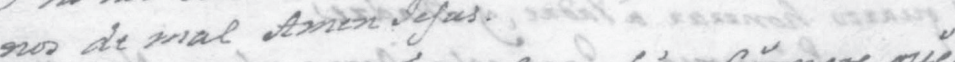

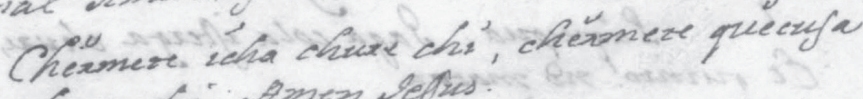

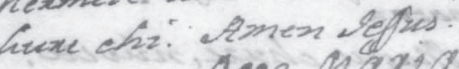

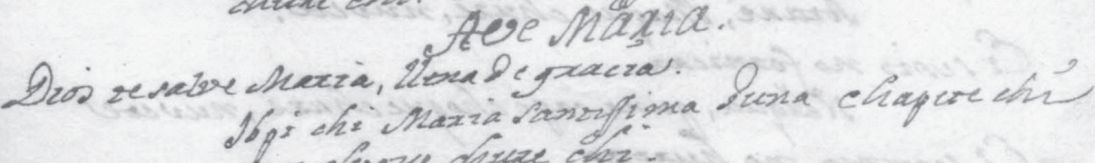

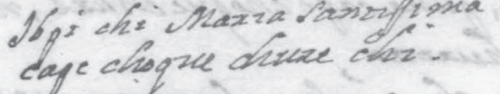

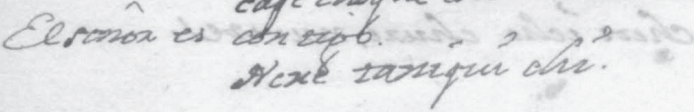

Figura 4. Cathesismo en lenguaje de los Yndios Cunacunas (página inicial).

Fuente: Biblioteca Nacional de Colombia, Fondo Cuervo 2613, pieza 4, f. 2, 1722 . 
Los ejemplos anteriores muestran cómo el ejercicio catequístico consistía en la repetición de ciertos enunciados y, de esta manera, el aprovechamiento del lenguaje como elemento fundamental en la construcción de verdades, al no solo permitir la reafirmación de determinadas formas de pensar en sintonía con la moral cristiana, sino además la creación de imágenes y realidades, dado que los catecismos se complementaron, y en cierta forma sustentaron en la iconografía barroca centrada en aspectos religiosos tales como la vida de los santos, escenas de la Biblia e imágenes ejemplarizantes que sugerían un modelo. Desde el siglo XVI hasta bien entrado el XVIII, la descripción caracterizó tanto la retórica como el arte pictórico, por lo que en este periodo se narró y pintó lo que se quería enseñar y lo que se pretendía "moralizar", es decir, fue una herramienta de doble vía que legitimó los procesos educativos y evangelizadores con el argumento de adoctrinar y "civilizar" a la heterogénea población americana o neogranadina. Así, palabra e imagen fueron las herramientas implementadas para educar y evangelizar.

La presencia e importancia de la Iglesia católica en todos los órdenes de la vida durante el periodo de dominación española también se reflejó en las artes, por lo que la arquitectura, la pintura y la poesía representaron el fuerte espíritu religioso de la época. Gaspar de Figueroa y Gregorio Vásquez de Arce y Ceballos fueron los máximos representantes en cuanto a la pintura y su función pedagógica, que cumplía un papel trascendental dado que la mayoría de la población no sabía leer y, por tal motivo, las imágenes eran el formato que permitía acercarse a las enseñanzas de la Iglesia y entender de manera más sencilla los discursos pronunciados desde los púlpitos en relación con la doctrina eclesiástica, los misterios, la vida ejemplar de Jesús, los evangelios de los apóstoles, las vidas de algunos santos y las consecuencias de no seguir los preceptos instaurados, tratados por demás en catecismos y novenas (Benavides, 2014).

Imágenes religiosas como La sagrada familia evidenciaban aquellas descripciones ideales que debían servir como ejemplo de vida para la población neogranadina, y eran complementadas por escritos también descriptivos como los catecismos y las novenas para difundir formas de comportamiento privadas y sociales en consonancia con los valores cristianos propios del sujeto de este periodo. Sin embargo las novenas se diferencian de los catecismos en su estructura y lenguaje por una razón particular: su brevedad y la sencillez de las palabras empleadas para explicar los hechos religiosos, incluyendo reflexiones, gracias e intenciones, lo cual permitió su rápida adopción al brindar la posibilidad de ser rezadas de manera más continua y en distintos espacios. 


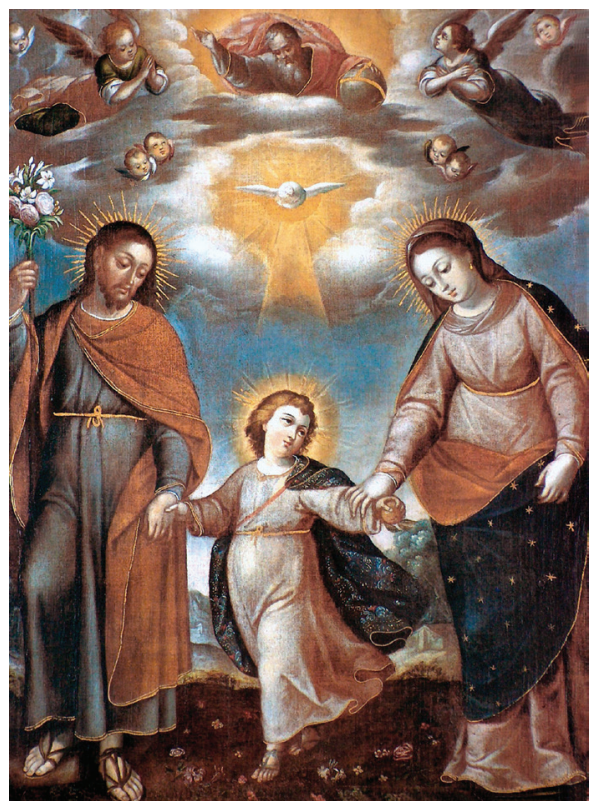

Figura 5. Sagrada familia y la Trinidad. Gregorio Vázquez de Arce y Ceballos. Óleo sobre tela, 1637. Museo de Arte Colonial, n. ${ }^{\circ}$ de Inventario 020.

Fuente: Instituto Colombiano de Cultura (1996, p. 43).

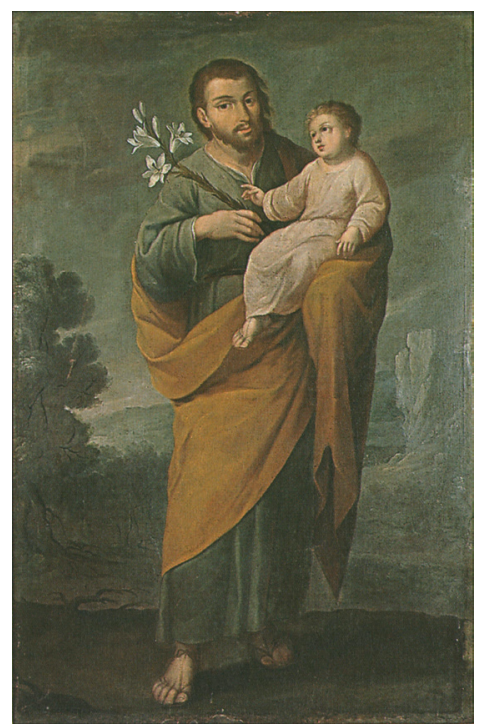

Figura 6. San José con el Niño. Gregorio Vásquez de Arce y Ceballos. Óleo sobre tela, 1701. Museo de Arte Colonial, n. ${ }^{\circ}$ de Inventario 022.

Fuente: Instituto Colombiano de Cultura (1996, p. 51). 
Las novenas producen prácticas que superan la simple repetición de los catecismos pensados básicamente para evangelizar, y generan un discurso específico que persuade al individuo mediante la recurrencia a cierto tipo de verdad moral (caridad, humildad, etc.) sobre la cual orientar su acción, constituyéndose así una intención dirigida a preparar una celebración religiosa o la misma salvación.

En la tradición católica, una novena es un ejercicio devocional practicado durante nueve días, con el propósito de obtener una gracia o intención especial de parte de Dios, Jesús o el Espíritu Santo, o una intercesión de parte de la Virgen María o de un santo particular. Esta práctica se remonta a los orígenes mismos del cristianismo, cuando la costumbre griega y romana de hacer nueve días de duelo por los difuntos fue reinterpretada a partir de peticiones atribuidas por Jesús a sus apóstoles de orar con insistencia (Lucas 18: 11) y de prepararse con tales oraciones para la venida del Espíritu Santo (Hechos 2: 1-41). Ya en la fase Patrística de la historia de la Iglesia, es posible encontrar reflexiones sobre el valor de las novenas para alcanzar a Dios. Posteriormente, y de acuerdo con la diversificación de las intenciones de las novenas, éstas se convierten en prácticas vinculadas a la preparación para fiestas o en general para la vida eterna (Arias, 2013, p. 41).

El discurso de las novenas permite mostrar el proceso de adoctrinamiento de la Iglesia en la población tanto del Viejo Continente como del Nuevo Mundo, al acompañar la enseñanza de devociones y oraciones con procesos descriptivos de la vida ejemplar de las figuras centrales de la tradición cristiana y de los santos, agregándole ciertos beneficios como la ganancia de favores e indulgencias, lo cual facilita la comprensión y discernimiento de los misterios de la fe con cierta dificultad de asimilación dada su gran carga teológica. Para ello existen tres tipos de novenas:

Primero, las novenas para pública o privada oración por una intención especial. Son las novenas dirigidas a Dios, a la Virgen o a los Santos, según su especialidad. Segundo, las novenas de preparación a fiestas que se hacen nueve días antes de la celebración y durante los ocho días posteriores, si son fiestas con Octavario. Y tercero, las novenas relacionadas con la muerte (funeral, novenario 
de difuntos. para pedir la gracia de una buena muerte, al Ánima sola...). La angustia, la fiesta y la muerte son los tres parámetros de las novenas. Las personas tratan de asumir momentos límites de la existencia, superar la tragedia de la vida cotidiana y hacer su recreación festiva, ayudadas por la novena. Hay que tener presente que la palabra "Novena" no indica sólo el texto escrito que se reza, sino también, el espacio temporal de los nueve días. Así mismo, hacer la novena no implica la lectura de un texto prefijado pues se tiene también otras formas como la celebración de misas, salves o simplemente algunas prácticas religiosas (Arboleda, 1999, p. 45).

Las novenas se configuran entonces como un catecismo desglosado, sencillo de entender y practicar en la cotidianidad, que permite obtener ganancias espirituales $\mathrm{y}$, sobre todo, acercarse a algunos aspectos religiosos fundamentados en una sacralidad más cercana al individuo. Se trata de prácticas que reevalúan y actualizan una determinada creencia que adquiere mayor trascendencia y persistencia en el tiempo por cuenta de la asimilación de lo sagrado en la cotidianidad, por lo que su constancia genera cierta institucionalización como ritual que en la medida en que se realiza durante los nueve días posibilita un vínculo más cercano entre el creyente y la potencia divina o sagrada.

Como textos devocionales, su lectura y práctica tiene lugar en escenarios privados y públicos, puesto que puede realizarse tanto en templos como en hogares, de modo que las novenas pasan a ocupar un lugar importante en la población americana no solo por contribuir a la evangelización y a la educación en la moral cristiana de manera general, sino para alcanzar la esfera privada e incluso íntima de las personas que las asumen como prácticas que posibilitan un contacto más directo con lo sagrado, siendo los mismos sujetos quienes buscan su propia salvación.

La estructura de las novenas respondía a su intención pedagógica por cuanto se detallaba el paso a paso que debía seguirse para el ejercicio de la devoción particular, por lo que su práctica, lectura y entendimiento resultaban más sencillos. En un primer momento, aparecía la guía para santiguarse y dar inicio a la novena, después —en la mayoría de los textos—, se encontraba un apartado titulado "Modo de hacer esta novena", en el que se describía el procedimiento y las recomendaciones para tener en cuenta, posteriormente se hallaban las oraciones para todos los días y la reflexión para cada día en particular, seguida finalmente de algunos gozos o antífonas. 
Estas partes que conformaban una novena fueron recurrentes en aquellas que durante los siglos XVI a XVIII se consolidaron en el territorio neogranadino, siendo las dedicadas a la Inmaculada Concepción, Nuestra Señora de las Nieves, la Santa Cruz, santa Bárbara, san Antonio, san Cristóbal, san Juan, la Virgen del Rosario y la Virgen del Topo las más practicadas, al igual que en otras de petición y ruego como la Novena para mugeres preñadas, y para las estériles, e incluso prácticas similares con una duración de siete días como el Septenario al Espiritu Santo. Todos estos textos contenían recomendaciones similares como asistir a misa, confesarse y comulgar, dar diezmos o contribuir con obras pías y rezar determinadas oraciones. La Novena a san Antonio, por ejemplo, plantea:

Se ha de confesar y comulgar uno de los nueve días, y se ha de ayunar, y no pudiendo se hará alguna otra obra buena, como es, una limosna, oír una misa, visitar los altares, rezar la Corona [...] Encenderá una vela en el altar del Santo, y no pudiendo, encienda su corazón con muchos actos de amor de Dios y de San Antonio.

Es así como durante el periodo de dominación española, las novenas resultaban prácticas comunes que, asociadas o no con celebraciones religiosas, cumplían no solo con su función devocional y evangelizadora, sino especialmente formativa dado su gran potencial como herramienta de reproducción de valores cristianos como la bondad, la caridad y la compasión.

Para que las novenas pudieran servir como herramientas devocionales y pedagógicas en relación con las virtudes cristianas, se requirió la llegada al territorio neogranadino del aparato que revolucionó la cultura europea en el siglo XV: la imprenta, que permitía la reproducción de textos e imágenes con tinta sobre papel. De hecho, una de las dos primeras publicaciones conocidas del periodo hispánico es justamente la Novena del Corazón de Jesús de 1738, elaborada en la imprenta de la Compañía de Jesús en Santafé.

La imprenta jesuita, aunque pequeńa y con una producción esporádica de folletos y obras de carácter religioso como un septenario y varias novenas, fue la primera en instaurarse en el virreinato y estuvo a cargo del hermano Francisco de la Peña — primer impresor conocido- hasta la expulsión de la Compañía en 1767. Dos años después se sabe de la existencia en Cartagena de Indias de un impresor llamado José de Rioja, quien en 1769 publicó la Novena del Glorioso Mártir San Sebastián Patrón contra la Peste, de don Marcos Antonio de Ribera, presbítero de Santafé que no logró imprimirla en esta 


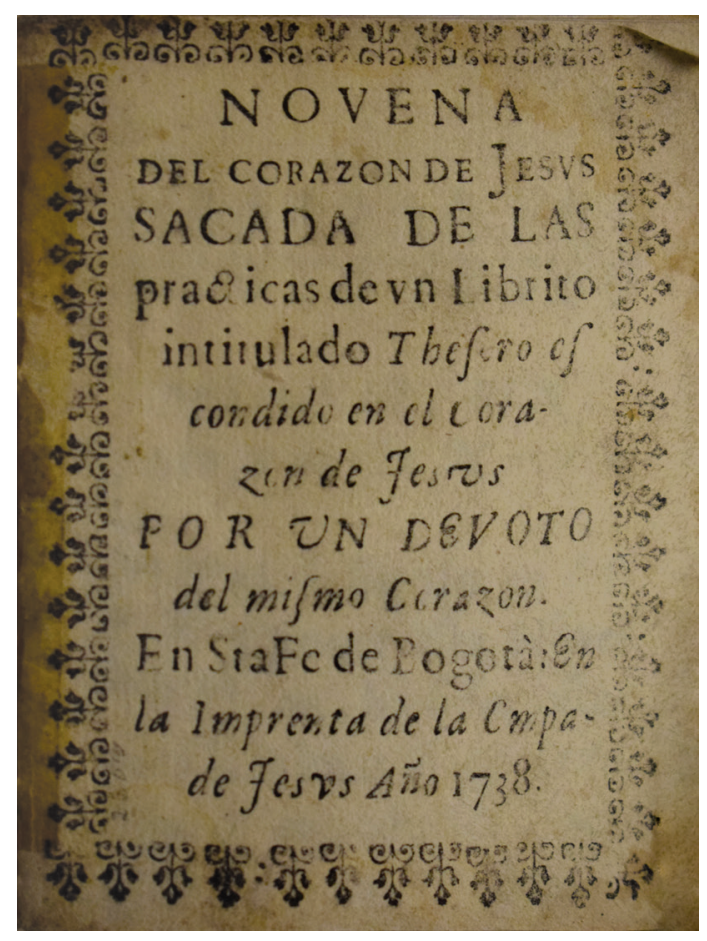

Figura 7. Página inicial Novena del Corazón de Jesús. Santafé de Bogotá, 1738.

Fuente: Biblioteca Luis Ángel Arango, Sala de Libros Raros y Manuscritos.

ciudad. Rioja vendió su imprenta en 1773 al español Antonio Espinosa de Los Monteros, vecino de la ciudad y fundador de una empresa familiar de vital importancia para la vida cultural del virreinato y de la independencia. Es así como se imprimió para 1774 en Cartagena el Octavario a la Inmaculada Concepción de la Virgen María Nuestra Señora del político santafereño Francisco Antonio Vélez Ladrón de Guevara, y la Novena del Felicissimo Transito de Maria Santissima Nuestra Señora del fraile quiteño Fernando de Jesús Larrea, personajes sobre los que se hablará más adelante.

Dada la importancia de contar con una imprenta oficial, el virrey don Manuel Antonio Flórez Maldonado — quien gobernó entre 1776 y 1781 ordenó la compra de una "imprenta grande" para Santafé, lo cual no fue posible por causa de los problemas económicos de la Corona. Sin embargo en 1777 se improvisó una imprenta con los restos de la expropiada a los jesuitas y la de Espinosa de Los Monteros, quien sería entonces el encargado de la imprenta real por su experiencia y reconocimiento. Esta fue la primera en publicar calendarios, hacer de conocimiento público las reformas administrativas e 
imprimir carteles e informaciones sobre higiene y control de epidemias en el virreinato, pero también continuó con la tradición de imprimir catecismos, novenarios y sermones. De este modo, las prácticas religiosas que requerían del medio escrito para ser desarrolladas se beneficiaron, puesto que podían conservar su carácter individual o ser compartidas en grupo en el caso de que se practicaran en las iglesias o en los hogares mismos.

La religiosidad en el periodo hispánico, cargada de términos tanto discursivos, a través de catecismos y novenas, como prácticos por cuenta de las múltiples celebraciones propias del calendario litúrgico, estaba centrada en la constante búsqueda de la salvación y la construcción de la moral cristiana, lo que sirvió como base y fuente de inspiración de la Novena para el Aguinaldo, de la que se desconoce la fecha exacta en que fray Fernando de Jesús Larrea pudo escribirla, no obstante, es posible mostrar la vida de su autor y entender sus motivaciones para hacerla, así como vislumbrar una probable relación que determinaría la llegada de este texto a Santafé y su acogida en una comunidad particular, de lo cual tratará el siguiente capítulo. 
